\title{
Mycobacterium caprae transmission to free-living grey wolves (Canis lupus) in the Bieszczady Mountains in Southern Poland
}

\author{
Blanka Orlowska $^{1}$ • Ewa Augustynowicz-Kopeć ${ }^{2}$ - Monika Krajewska ${ }^{3}$ - Anna Zabost ${ }^{2}$. \\ Miroslaw Welz ${ }^{4} \cdot$ Stanislaw Kaczor $^{5} \cdot$ Krzysztof Anusz $^{1}$
}

Received: 16 July 2016 / Revised: 30 October 2016 / Accepted: 2 January 2017 / Published online: 14 January 2017

(C) The Author(s) 2017. This article is published with open access at Springerlink.com

\begin{abstract}
The aim of this study was to assess whether animal tuberculosis (TB) is transmitted between free-living European bison (Bison bonasus caucasicus), wild boars (Sus scrofa), and protected carnivores such as grey wolves (Canis lupus), brown bears (Ursus arctos), and Eurasian lynx (Lynx lynx) in the Bieszczady Mountains in Southern Poland. Results of animal studies suggest that TB transmission from bison or wild boars to grey wolves is possible. These are the first described cases where Mycobacterium caprae was detected in samples collected from grey wolves.
\end{abstract}

Keywords Mycobacterium caprae · Grey wolf · Tuberculosis transmission $\cdot$ European bison $\cdot$ Wild boar

\section{Introduction}

Over the last 20 years, in Poland, most cases of animal tuberculosis (TB) have been identified in the Bieszczady

Blanka Orłowska

orlowska.blanka@gmail.com

1 Department of Food Hygiene and Public Health Protection, Faculty of Veterinary Medicine, Warsaw University of Life Sciences (SGGW), Nowoursynowska 166, 02-787 Warsaw, Poland

2 Tuberculosis and Lung Disease Institute, Płocka 26, 01-138 Warsaw, Poland

3 Department of Microbiology, National Veterinary Research Institute, Partyzantów 57, 24-100 Puławy, Poland

4 Provincial Veterinary Inspectorate, Piotra Sciegiennego 6 A, 38-400 Krosno, Poland

5 County Veterinary Inspectorate, Młynarska 45, 38-500 Sanok, Poland
Mountains (Podkarpackie Voivodeship). In this region, TB (mainly Mycobacterium caprae) was found in European bison (Bison bonasus caucasicus) and wild boar (Sus scrofa). Over the period 1996-2000 and 2010-2013, there were 14 and 31 TB cases detected in European bison, respectively, (the population of European bison in the Bieszczady mountains was estimated at 256 individuals in 2013) (Krajewska et al. 2015c). In wild boars, the first case of TB was found in 2013. By 2015, there were confirmed 27 cases of TB in this species, although the actual number of such cases remains unknown (Krajewska et al. 2014, 2015a). According to the Voivodeship Veterinary Inspectorate, TB has not been reported in domestic animals in the Bieszczady Mountains in the Podkarpackie Voivodeship since 2005. In the Bieszczady County, cattle are screened for TB once a year.

The Bieszczady Mountains constitute one of the most valuable wildlife refuges in Poland. They are home for many protected animals, including grey wolves (Canis lupus), brown bears (Ursus arctos), and Eurasian lynx (Lynx lynx). Reports of TB cases in European bison and wild boars in this territory raised suspicion as to a possible transmission of this disease between wildlife in the Bieszczady Mountains, including the above-mentioned carnivores.

The population of grey wolf is the biggest among large predators inhabiting the Bieszczady Mountains. According to estimates, there are 65-100 grey wolves only in the Bieszczady Mountains, which cover the forest area of approximately $1600 \mathrm{~km}^{2}$ (Śmietana 2000). For grey wolves inhabiting the Bieszczady Mountains, the major dietary components are red deer (Cervus elaphus) (over $70 \%$ of consumed biomass), European roe deer (Caporeolus capreolus) (5-10\% of consumed biomass), and wild boar (Sus scrofa) (2-10\% of consumed biomass). Domestic animals are attacked very rarely (over $80 \%$ of attacks concern sheep) (Śmietana and Wajda 1997; Gula 2008; Jędrzejewski et al. 2012). 
The aim of this study was to assess whether TB is transmitted between free-living animals, i.e., European bison and wild boar, and protected carnivores such as grey wolf, brown bear, and Eurasian lynx in the Bieszczady Mountains in Poland.

\section{Material and methods}

\section{Study area}

Study material was collected in the Polish Bieszczady Mountains and its neighboring territories. The Bieszczady Mountains, which are part of the Eastern Carpathian Mountains, are situated in the Podkarpackie Voivodeship in the southernmost region of Poland bordering with Ukraine and Slovakia. It is characterized with high forestation rate and population density amounting to $20-79$ people per $\mathrm{km}^{2}$ (Cierpiał-Wolan et al. 2013).

\section{Sample collection}

Material for TB microbiological assays was sampled from grey wolves, brown bears, and Eurasian lynx between January 2011 and April 2013. It was collected from dead individuals, i.e., victims of road accidents or poaching, and showed various degrees of tissue decomposition. The animals were found by qualified forest workers (no radiotracking) who estimated the age of animals by the state of their teeth. The responsibility for necropsies and material collection lied with authorized veterinary inspectors. The study material comprised all available lymph nodes. It was collected from nine wolves (marked 1 to 9), a bear, and a lynx (Table 1). Table 1 shows the locations in which the animals were found and types of sampled lymph nodes. Due to advanced tissue decomposition, lymph nodes collected from wolves 1, 2, 3, 5, and 6 constituted combined samples, each one from an individual animal. In other wolves $(4,7,8,9)$, lynx, and bear, each lymph node was cultured separately. For the purposes of tissue culture, lymph nodes were used in whole. Their macroscopic examination had been carried out earlier.

\section{Culture and molecular analysis}

\section{Mycobacteria isolation}

The collected animal material was subject to conventional microbiological procedures to isolate mycobacteria. The material was ground and homogenized in a $5 \%$ oxalic acid (OA). Next, it was flushed twice in a sterile sodium chloride solutions $(\mathrm{NaCl}, 0.9 \%)$. The sediment was inoculated onto the Lowenstein-Jensen and Stonebrink media (Oxoid, Germany) and incubated at $37^{\circ} \mathrm{C}$ for 12 weeks.

\section{Molecular analysis}

Molecular identification of strains was first based on the hsp65 sequence analysis (Telenti et al. 1993). As this method does not differentiate species within a group of Mycobacterium tuberculosis complex, further identification of strains was performed using the GenoType ${ }^{\circledR}$ MTBC (Hain Lifescience, Germany) molecular test, spoligotyping method, and MIRU-VNTR analysis.

The GenoType MTBC assay was performed in accordance with the manufacturer's instructions. The spoligotyping was performed as described previously by Kamerbeek et al.
Table 1 Information on 11 carnivores found in the Bieszczady Mountains between 2011 and 2013 and summary of microbiological test results of the collected material

\begin{tabular}{|c|c|c|c|c|c|}
\hline $\begin{array}{l}\text { Predatory } \\
\text { species }\end{array}$ & Gender & Age & Sample type & $\begin{array}{l}\text { TB test } \\
\text { result }\end{array}$ & $\begin{array}{l}\text { Discovery site: commune/ } \\
\text { county }\end{array}$ \\
\hline Grey wolf (1) & $\mathrm{N} / \mathrm{D}$ & $\mathrm{N} / \mathrm{D}$ & $1+3 \mathrm{CS}$ & - & Rymanów/Krosno County \\
\hline Grey wolf (2) & $\mathrm{N} / \mathrm{D}$ & $\mathrm{N} / \mathrm{D}$ & $1+3 \mathrm{CS}$ & - & Targowiska/Krosno County \\
\hline Grey wolf (3) & $\mathrm{N} / \mathrm{D}$ & $\mathrm{N} / \mathrm{D}$ & $1+3 \mathrm{CS}$ & - & Rymanów/Krosno County \\
\hline Grey wolf (4) & $\mathrm{F}$ & 1 & $1,2,3,4$ & - & Rymanów/Krosno County \\
\hline Grey wolf (5) & M & 4 & $1+2+3+4 \mathrm{CS}$ & M. caprae & Lutowiska/Bieszczady County \\
\hline Grey wolf (6) & M & 8 & $1+2+3+4 \mathrm{CS}$ & - & Lutowiska/Bieszczady County \\
\hline Grey wolf (7) & M & $\mathrm{N} / \mathrm{D}$ & $1,2,3,4,5$ & - & Jawornik/Sanok County \\
\hline Grey wolf (8) & $\mathrm{F}$ & 2 & 2 & M. caprae & Rabe/Bieszczady County \\
\hline Grey wolf (9) & M & 4 & $\begin{array}{l}\text { Retropharyngeal } \\
\text { LNs }\end{array}$ & M. caprae & Dwernik/Bieszczady County \\
\hline Eurasian lynx & $\mathrm{N} / \mathrm{D}$ & $\mathrm{N} / \mathrm{D}$ & 1,2 & - & Baligród/Lesko County \\
\hline Brown bear & $\mathrm{F}$ & 12 & 1 & _- & Buk/Lesko County \\
\hline
\end{tabular}

Animal material: 1 - mandibular and retropharyngeal lymph nodes (LNs), 2-mediastinal LNs, 3-hepatic LNs, 4 - mesenteric LNs, 5 - popliteal and sub-iliac LNs

$M$ male, $F$ female, $N / D$ no data, $C S$ combined sample 
(1997). For the purposes of database comparison, spoligotypes were entered in a binary form into the SpolDB4 proprietary database of the Pasteur Institute of Guadeloupe (Brudey et al. 2006). The MIRU-VNTR typing was performed with a use of a published protocol (AlonsoRodríguez et al. 2008).

Mycobacterium caprae strains collected from wild boars and European bison in the Bieszczady Mountains were examined in previous studies (Krajewska et al. 2014; Krajewska et al. 2015a, b; Orłowska B. unpublished results), in which identical isolation and molecular analysis procedures were performed. The obtained strains were compared with Mycobacterium caprae strains isolated from wolves and described in this study.

\section{Results}

Mycobacterium caprae was detected in material collected from three dead wolves in the Bieszczady County: a fouryear-old male found near Lutowiska $\left(49^{\circ} 15^{\prime} 03.8^{\prime \prime} \mathrm{N} 22^{\circ}\right.$ $\left.41^{\prime} 43.5^{\prime \prime} \mathrm{E}\right)$, a two-year-old female found near Rabe $\left(49^{\circ}\right.$ $21^{\prime} 38.7^{\prime \prime} \mathrm{N} 22^{\circ} 40^{\prime} 12.5^{\prime \prime} \mathrm{E}$ ), and a four-year-old male found near Dwernik (49 $\left.12^{\prime} 39.4^{\prime \prime} \mathrm{N} 22^{\circ} 37^{\prime} 37.1^{\prime \prime} \mathrm{E}\right)$, which are marked as wolves number 5,8 , and 9 , respectively (Table 1). The isolates collected from wolves no. 5 and 8 shared an identical spoligotype (200003777377600), which is already classified in SpolDB4. However, the isolate from wolf no. 9 showed a new spoligotype (200003777377400). These two spoligotypes differ from each other only with presence or absence of the 38 spacer within the DR studied. All three strains of Mycobacterium caprae were identified with one MIRU-VNTR pattern (463552362413223).

The animals studied did not show any pathological lesions typical of TB.

The comparison of Mycobacterium caprae strains isolated from wolves with strains isolated from wild boars and
European bison in the Bieszczady Mountains is presented in Table 2.

\section{Discussion}

The study conducted on samples collected from grey wolves in the Bieszczady Mountains revealed TB infections in three out of nine investigated individuals. These are the first documented cases of Mycobacterium caprae isolation from grey wolves in Poland. No mycobacteria were cultured from samples collected from brown bears or Eurasian lynx. The number of investigated animals was insufficient to draw any conclusions regarding the TB prevalence in this group of predators.

Under the Regulation of the Minister of Environment of 6 October 2014 on the protection of animal species (Polish Journal of Laws of 2014, Item 1348), grey wolves, Eurasian lynx, and brown bears are all protected species. Therefore, the study material could only include samples collected from animals that were found dead. Each of them constituted a valuable research material. In this study, Mycobacterium caprae was isolated from three wolves: a male from Lutowiska (wolf no. 5), a female from Rabe (wolf no. 8), and a male from Dwernik (wolf no. 9) (Table 1). As it results from molecular comparison of strains isolated from these three wolves and the strains isolated earlier from bison and wild boars in the Bieszczady Mountains, all these strains share the same chain of transmission (Table 2). The MIRU-VNTR analysis showed very similar molecular patterns in strains isolated from five European bison, a wild boar from Nasiczne, and wolf no. 9. They shared an identical spoligotype, but their MIRU-VNTR pattern differed in one or two loci. As it follows from the literature, if strains differ in repetitive units from one locus, it may indicate a very close phylogenetic relationship (Savine et al. 2002; Alonso-Rodríguez et al. 2008). The strains obtained from two wild boars in Ruskie village (Lutowiska Commune) had a spoligotype 200003777377600 (Orłowska

Table 2 Molecular characteristic and comparison of Mycobacterium caprae strains isolated from grey wolves, wild boars, and European bison ("Górny San" herd) in the Bieszczady Mountains

\begin{tabular}{lllll}
\hline Strain/animal description & Octal designation & $\begin{array}{l}\text { Spoligotype family with } \\
\text { reference to SpolDB4 }\end{array}$ & MIRU-VNTR pattern & Source literature \\
\hline Wolf no. 5 from Lutowiska & 200003777377600 & CAP & 463552362413223 & Study results \\
Wolf no. 8 from Rabe & 200003777377600 & CAP & 463552362413223 & \\
Wolf no. 9 from Dwernik & 200003777377400 & Unregistered & 463552362413223 & Orlowska, B., unpublished results \\
Wild boars from Ruskie (2 animals) & 200003777377600 & CAP & 463552362413223 & Krajewska et al. 2014 \\
Wild boar from Nasiczne & 200003777377400 & Unregistered & 453552362412223 & Krajewska et al. 2015a, b \\
European bison (10 animals $)$ & 200003777377400 & Unregistered & 453552362412223 & \\
European bison (1 animal) & 200003777377400 & Unregistered & 423552342411223 & \\
European bison (1 animal) & 200003777377400 & Unregistered & 423552362411223 & \\
European bison (5 animals $)$ & 200003777377400 & Unregistered & 453552362413223 & \\
\hline
\end{tabular}


B. unpublished results) identical with the spoligotype of strains isolated from wolves no. 5 and 8. Based on MIRUVNTR genotyping, the strains isolated from wolves no. 5 and 8 , as well as strains from wild boars found in the Lutowiska Commune, formed one cluster.

Grey wolves inhabiting the Bieszczady Mountains prey mainly on red deer, wild boar, and European roe deer, in descending order (Śmietana and Wajda 1997; Jędrzejewski et al. 2012). No attacks on European bison have been observed, although feeding on bison's carcasses was reported (Śmietana and Wajda 1997). Livestock is rarely attacked (mainly sheep). The last known TB case in domestic animals in the Bieszczady Mountains was reported in a cow in 2005. No acts of cannibalism were described nor observed in the studied population of grey wolf in Poland. Based on this work and previous studies on molecular analysis of mycobacteria strains isolated from animals in the Bieszczady Mountains, the assumed source of Mycobacterium caprae infection in wolves is the carcasses of ungulates, wild boars, or European bison. No cases of TB were reported in red deer in the Bieszczady Mountains. Further investigation of this species is warranted (Orłowska et al. 2014). TB-weakened animals with clinical symptoms of the disease may be easily spotted by wolves and become their prey. Thus, in the Bieszczady Mountains, wolves may play an important regulatory role in the population of TB-infected wild ungulates.

The wolves studied in this research did not show any macroscopic lesions typical of TB and were not clinically affected by TB, thus, they probably did not shed any mycobacteria to the environment. However, wolves inhabiting the Bieszczady Mountains often fall victim to road accidents and poaching, so their carcasses may be the source of TB transmission. It remains unknown whether wolves could shed any viable mycobacteria in their feces after consuming TB-infected prey. It requires further investigation.

Some cases of TB transmission to wild carnivores are described in the literature (Santos et al. 2012; Viljoen et al. 2015). Other studies also show that certain carnivorous species, including coyotes, may be used to detect tuberculosis (Berentsen et al. 2011). VerCauteren et al. (2008) found that obtaining samples from coyotes rather than deer increases the likelihood of detecting Mycobacterium bovis by $40 \%$ in TBendemic areas. In our study, three out of nine investigated wolves were infected with Mycobacterium caprae. Thus, in the Bieszczady Mountains, it may be useful to monitor TB with samples from wolves, although it is difficult due to their status of endangered and protected species.

Wolves are highly territorial animals, but individuals may occasionally disperse and travel long distances despite any physical or anthropogenic barriers (Blanco et al. 2005). TBinfected wolves could theoretically have migrated to the Bieszczady Mountains from some other place where they might have become infected. However, although it is theoretically possible, the most likely source of infection is the transmission of TB from infected wild ungulates inhabiting the examined area.

\section{Conclusion}

The study revealed the transmission of TB (Mycobacterium caprae) to grey wolves in the Bieszczady Mountains. The most likely source of infection is the carcasses of wild boars and European bison. It appears that constant monitoring of TB in wildlife inhabiting the Bieszczady Mountains is necessary.

Acknowledgements The authors wish to thank Jan Mazur from the Stuposiany Forest Inspectorate in the Bieszczady Mountains in Southern Poland for animal sampling and helpful comments on the manuscript.

\section{Compliance with ethical standards}

Financial resources The statutory activity of National Tuberculosis and Lung Diseases Research Institute, Task No 1.23.

Conflict of interest The authors declare that they have no conflict of interest.

Open Access This article is distributed under the terms of the Creative Commons Attribution 4.0 International License (http:// creativecommons.org/licenses/by/4.0/), which permits unrestricted use, distribution, and reproduction in any medium, provided you give appropriate credit to the original author(s) and the source, provide a link to the Creative Commons license, and indicate if changes were made.

\section{References}

Alonso-Rodríguez N, Martínez-Lirola M, Herránz M, Sanchez-Benitez M, Barroso P (2008) Evaluation of the new advanced 15-loci MIRU-VNTR genotyping tool in Mycobacterium tuberculosis molecular epidemiology studies. BMC Microbiol 8:34

Berentsen AR, Dunbar MR, Johnson SR, Robbe-Austerman S, Martinez L, Jones R (2011) Active use of coyotes (Canis latrans) to detect Bovine Tuberculosis in northeastern Michigan, USA. Vet Microbiol 151:126-132

Blanco JC, Cortés Y, Virgós E (2005) Wolf response to two kinds of barriers in an agricultural habitat in Spain. Can J Zool 83:312-323

Brudey K, Driscoll JR, Rigouts L et al (2006) Mycobacterium tuberculosis complex genetic diversity: mining the fourth international spoligotyping database (SpolDB4) for classification, population genetics and epidemiology. BMC Microbiol 6:23

Cierpiał-Wolan M, Jasiukiewicz D, Krzemińska T, Markocki P, Polak I, Tworek-Ptak A, Uchman J, Wojnar E, Wojtak J (2013) Podkarpackie Voivodship - Subregions, Powiats, Gminas. Statistical Office in Rzeszów. ISSN 1733-0041

Gula R (2008) Wolf depredation on domestic animals in the Polish Carpathian Mountains. J Wildl Manag 72:283-289

Jędrzejewski W, Niedziałkowska M, Hayward MW, Goszczyński J, Jędrzejewska B, Borowik T, Bartoń KA, Nowak S, 
Harmuszkiewicz J, Juszczyk A, Kałamarz T, Kloch A, Koniuch J, Kotiuk K, Mysłajek RW, Nędzyńska M, Olczyk A, Telon M, Wojtulewicz M (2012) Prey choice and diet of wolves related to ungulate communities and wolf subpopulations in Poland. J Mammal 93:1480-1492

Kamerbeek J, Schouls L, Kolk A, van Agterveld M, van Soolingen D, Kuijper S, Bunschoten A, Molhuizen H, Shaw R, Goyal M, van Embden J (1997) Simultaneous detection and strain differentiation of Mycobacterium tuberculosis for diagnosis and epidemiology. J Clin Microbiol 35:907-914

Krajewska M, Lipiec M, Zabost A, Augustynowicz-Kopeć E, Szulowski K (2014) Bovine tuberculosis in a wild boar (Sus scrofa) in Poland. J Wildl Dis 50:1001-1002

Krajewska M (2015a) Charakterystyka szczepów Mycobacterium bovis izolowanych od zwierząt w Polsce. Doctoral thesis. National Veterinary Research Institute, Puławy, Poland

Krajewska M, Kozińska M, Orłowska B, Welz M, AugustynowiczKopeć E, Anusz K, Szulowski K (2015b) Molecular analysis methods in epidemiological investigations of animal tuberculosis in European bison. Europ Bison Conserv Newslett 8:79-86

Krajewska M, Zabost A, Welz M, Lipiec M, Orłowska B, Anusz K, Brewczyński P, Augustynowicz-Kopeć E, Szulowski K, Bielecki W, Weiner M (2015c) Transmission of Mycobacterium caprae in a herd of European bison in the Bieszczady Mountains, Southern Poland. Eur J Wildl Res 61:429-433

Orłowska B, Anusz K, Krajewska M, Augustynowicz-Kopeć E, Zabost A, Nowicki M (2014) Recognition of the M. tuberculosis complex reservoirs among free-ranging red deer (Cervus elaphus) in the
Bieszczady region (south-eastern Poland). XIV Middle European Buiatrics Congress, Warsaw, 167

Santos N, Correia-Neves M, Almeida V, Gortázar C (2012) Wildlife tuberculosis: a systematic review of the epidemiology in Iberian Peninsula. In: Dr. Maria De Lourdes Ribeiro De Souza Da Cunha (ed) Epidemiology Insights. InTech, pp 273 -294 DOI: 10.5772/ 33781

Savine E, Warren RM, van der Spuy GD, Beyers N, van Helden PD, Locht C, Supply P (2002) Stability of variable-number tandem repeats of mycobacterial interspersed repetitive units from 12 loci in serial isolates of Mycobacterium tuberculosis. J Clin Microbiol 40: $4561-4566$

Śmietana W (2000) The wolf population in the Bieszczady Mountains. Monografie Bieszczadzkie 9:128-144

Śmietana W, Wajda J (1997) Wolf number changes in Bieszczady National Park, Poland. Acta Theriol 42:241-252

Telenti A, Marchesi F, Balz M, Bally F, Bottger EC, Bodmer T (1993) Rapid identification of mycobacteria to the species level by polymerase chain reaction and restriction enzyme analysis. J Clin Microbiol 31:175-178

VerCauteren KC, Atwood TC, DeLiberto TJ, Smith HJ, Stevenson JS, Thomsen BV, Gidlewski T, Payeur J (2008) Sentinel-based surveillance of coyotes to detect bovine tuberculosis, Michigan. Emerg Infect Dis 14:1862-1869

Viljoen IM, van Helden PD, Millar RP (2015) Mycobacterium bovis infection in the lion (Panthera leo): current knowledge, conundrums and research challenges. Vet Microbiol $177: 252-260$ 